\title{
Carbohydrate Metabolism in Two Forms of Hyperglyceridemia *
}

\author{
Jerome L. Knittle and E. H. Ahrens, Jr. \\ (From the Rockefeller Institute, New York, N. Y.)
}

In a previous report two forms of primary hyperglyceridemia ${ }^{1}$ were described, one caused by a failure to clear dietary fats at normal rates, the other induced by high-carbohydrate diets (1). Levels of serum triglycerides can be lowered in the former case by diets low in fat or diets in which long-chain fats are replaced by mediumchain fats (2). In carbohydrate-induced hyperglyceridemia, however, serum concentrations of triglycerides are reduced by substituting fat for carbohydrate in the diet.

Although future studies may develop a still more meaningful categorization of primary hyperlipemia, present experience $(1,3-6)$ indicates that many patients with high serum triglyceride concentrations fall into one of the two groups described, and further, that carbohydrate-induced hyperglyceridemia is the more common abnormality. Eleven of twelve adequately studied cases of fat-induced hyperlipemia $(1,3,7,8)$ have shown very low levels of lipoprotein lipase activity in the plasma after iv injection of heparin, a finding that appears to explain the characteristically slow clearance of chylomicrons from the circulating blood. However, the basic defect in carbohydrate-induced lipemia, in which lipoprotein lipase activity is normal, remains unclear. That the serum triglycerides arise by lipogenesis from carbohydrate rather than by mobilization of adipose tissue fatty acids has been demonstrated (1). Indeed, all mammalian organisms would be expected to convert a large proportion of dietary carbohydrate to fat when sugars are fed at high caloric levels, for ingested carbohydrate will ex-

\footnotetext{
* Submitted for publication August 1, 1963 ; accepted November 14, 1963.

Supported in part by U. S. Public Health Service grant HE-06222-02, National Heart Institute.

${ }^{1}$ In this report we shall not be concerned with the secondary hyperlipemias seen in nephrosis, starvation, hypothyroidism, glycogen storage disease, hemolytic anemia, or multiple myeloma.
}

ceed energy needs at certain times of the day, and storage in the form of glycogen is limited. Nevertheless, there remains the intriguing question of why some individuals have more than normal amounts of triglycerides in the plasma under such circumstances. That normal men develop hyperglyceridemia on high-carbohydrate diets has been demonstrated by Antonis and Bersohn (9), but the effect they described was small and transient, lasting only several months. Since certain populations that live habitually on high-carbohydrate, low-fat diets do not manifest hyperglyceridemia, normal men apparently adapt to a high-carbohydrate intake, and persistent carbohydrate-induced hyperglyceridemia seems to represent a metabolic abnormality.

Three observations suggest that patients with carbohydrate-induced hyperglyceridemia might have defective secretion or utilization of insulin: 1) in normal subjects carbohydrate ingestion is a major stimulus to insulin secretion $(10,11), 2)$ diabetics have lower concentrations of serum triglycerides when optimally managed with insulin than when untreated, even in the absence of acidosis $(12,13)$, and 3 ) mild diabetes develops as a sequel to hyperlipemia (14). 'These considerations led to the present study, which describes two parameters of carbohydrate metabolism in patients with the two forms of hyperglyceridemia. The findings indicate that an abnormality of carbohydrate metabolism exists in carbohydrate-induced hyperglyceridemia.

\section{Methods}

Clinical data (Table I). This report is based on studies of 23 patients: 10 carbohydrate-induced and 3 fat-induced hyperglyceridemia, 3 maturity-onset diabetes, and 7 controls with no evidence of diabetes or hyperglyceridemia. A comparison of tolbutamide responsiveness in the two forms of hyperglyceridemia was the primary focus of this study. In addition, small numbers of diabetic and of nondiabetic, nonhyperlipemic pa- 
TABLE I

\begin{tabular}{|c|c|c|c|c|c|c|c|}
\hline Patient & Age & Sex & $\begin{array}{c}\text { Coronary } \\
\text { heart } \\
\text { disease }\end{array}$ & $\begin{array}{c}\text { Peri- } \\
\text { pheral } \\
\text { vascular } \\
\text { disease }\end{array}$ & $\begin{array}{l}\text { Xantho- } \\
\text { matosis }\end{array}$ & $\begin{array}{c}\text { Acute } \\
\text { abdom- } \\
\text { inal } \\
\text { crises }\end{array}$ & $\begin{array}{l}\text { Family history } \\
\text { of diabetes }\end{array}$ \\
\hline & years & & & & & & \\
\hline \multicolumn{8}{|l|}{ Normal } \\
\hline C.B. & 34 & $\sigma^{7}$ & $0 \|$ & 0 & 0 & 0 & \multirow{2}{*}{$\begin{array}{c}\text { Mother at } \\
40 \text { years } \\
0 \\
0 \\
0 \\
0 \\
0 \\
0\end{array}$} \\
\hline $\begin{array}{l}\text { D.B. } \\
\text { R.C. } \\
\text { A.G. } \\
\text { P.A. } \ddagger \ddagger \\
\text { T.N. } \\
\text { A.R. }\end{array}$ & $\begin{array}{l}34 \\
36 \\
52 \\
47 \\
50 \\
62\end{array}$ & $\begin{array}{l}q \\
9 \\
0 \\
0^{7} \\
0^{7} \\
0^{7} \\
0^{7}\end{array}$ & $\begin{array}{l}0 \\
0 \\
\mathrm{X}+\dagger \\
0 \\
0 \\
0\end{array}$ & $\begin{array}{l}0 \\
0 \\
0 \\
0 \\
0 \\
\mathrm{X}\end{array}$ & $\begin{array}{l}0 \\
\mathrm{~T}^{* *} \\
0 \\
0 \\
0 \\
0\end{array}$ & $\begin{array}{l}0 \\
0 \\
0 \\
0 \\
0 \\
0\end{array}$ & \\
\hline \multicolumn{8}{|l|}{ Diabetes } \\
\hline $\begin{array}{l}\text { E.F. } \\
\text { R.W. } \\
\text { H.K. }\end{array}$ & $\begin{array}{l}62 \\
60 \\
50\end{array}$ & $\begin{array}{l}0^{7} \\
0^{7} \\
9 \\
9\end{array}$ & $\begin{array}{l}\mathrm{X} \\
\mathrm{X} \\
\mathrm{X}\end{array}$ & $\begin{array}{l}\mathrm{X} \\
0 \\
0\end{array}$ & $\begin{array}{l}\mathbf{0} \\
0 \\
\text { S-T§§ }\end{array}$ & $\begin{array}{l}0 \\
0 \\
X\end{array}$ & $\begin{array}{l}0 \\
0 \\
0\end{array}$ \\
\hline \multicolumn{8}{|c|}{ Fat-induced hyperlipemia } \\
\hline $\begin{array}{l}\text { H.G. } \\
\text { C.M. } \\
\text { R.B. }\end{array}$ & $\begin{array}{r}4 \\
39 \\
8\end{array}$ & $\begin{array}{l}\sigma \\
\$ \\
\$ \\
\$\end{array}$ & $\begin{array}{l}0 \\
0 \\
0\end{array}$ & $\begin{array}{l}0 \\
0 \\
0\end{array}$ & $\begin{array}{l}S \\
S \\
0\end{array}$ & $\begin{array}{l}\mathrm{X} \\
\mathrm{X} \\
\mathrm{X}\end{array}$ & $\begin{array}{c}0 \\
0 \\
\text { Father at } \\
\text { 34 years }\end{array}$ \\
\hline
\end{tabular}

Carbohydrateinduced hyperglyceridemia

$\begin{array}{lllllllc}\text { G.J. } & 56 & q & 0 & 0 & 0 & \mathrm{X} & 0 \\ \text { T.M. } & 41 & \sigma^{7} & 0 & \mathrm{X} & \mathrm{S}-\mathrm{T} & 0 & 0 \\ \text { H.S. } & 42 & \sigma^{7} & 0 & 0 & \mathrm{~S} & 0 & 0 \\ \text { A.S. } & 41 & \sigma^{7} & 0 & \mathrm{X} & \mathrm{S} & 0 & 0 \\ \text { E.K. } & 64 & \sigma^{7} & \mathrm{X} & 0 & 0 & 0 & 0 \\ \text { L.S. } & 60 & \sigma^{7} & \mathrm{X} & 0 & 0 & 0 & 0 \\ \text { J.F. } & 30 & \sigma^{7} & 0 & 0 & \mathrm{~S}-\mathrm{T} & 0 & \begin{array}{c}\text { Mother at } \\ \text { S5 years }\end{array} \\ \text { R.K. } & & & & & 0 & & \\ \text { S.S } & 55 & \sigma^{7} & \mathrm{X} & 0 & 0 & 0 & 12 \text { at } \\ \text { J.S. } & 60 & \sigma^{7} & \mathrm{X} & 0 & 0 & 0 & 0 \\ \text { M.S. } & 56 & \wp & 0 & \mathrm{X} & 0 & 0 & 0\end{array}$

* Average of 3 or more weekly determinations during "steady state" (except normal patient, P.A. = single test). Normal values in this laboratory $=100$ to $300 \mathrm{mg}$ per $100 \mathrm{ml}$.

$\dagger$ Diet A: protein :fat:carbohydrate $(\mathrm{P}: \mathrm{F}: \mathrm{C}): 15: 0: 85 \%$ of total calories.

$\neq$ Diet B: P:F :C: $15: 40: 45 \%$ of total calories.

Diet $C: P: F: C: 15: 70: 15 \%$ of total calories.

$0=$ absent.

tients were tested to determine that the tolbutamide challenges produced responses comparable to those reported in much greater detail by previous workers.

Ten of our 19 patients with carbohydrate-induced hyperglyceridemia were studied, 2 females and 8 males, ages 30 to 64 years. (The other 9 patients were not available at the time of this study.) The sera of 7 of the 10 patients, on ad libitum diets, showed visible lipemia. Nine were studied for 4 to 8 months on the metabolic ward, and 1 (a physician, R.K.), as an outpatient. Seven of the 10 had coronary or peripheral vascular disease, 2 had tendinous xanthomata, and 4 had skin xanthomata. One had suffered repeated episodes of acute abdominal crises, and 2 had a family history of diabetes.
All of the these 10 patients had normal levels of lipoprotein lipase activity after iv heparin administration.

Three patients with fat-induced hyperlipemia were studied on the metabolic ward for 4 to 8 months. One (C.M., 39 years old) was studied as a child and described in 1939 by Holt, Aylward, and Timbres (15), the first reported case of hyperlipemia in the English literature; the others were 4 and 8 years old. All three had had episodes of acute abdominal pain diagnosed as acute pancreatitis, two had skin xanthomata, and one had a family history of diabetes, but none had evidence of arteriosclerosis. All had abnormally low levels of lipoprotein lipase activity in the plasma after iv heparin injection (1, 3). One (C.M.) had a family history of 
TABLE I

and dietary data

\begin{tabular}{|c|c|c|c|c|c|c|}
\hline \multicolumn{4}{|c|}{ Serum triglycerides* } & \multirow[b]{2}{*}{$\begin{array}{c}\text { Abnormal } \\
\text { response } \\
\text { to } \\
\text { glucagon }\end{array}$} & \multirow[b]{2}{*}{$\begin{array}{c}\text { Abnormal } \\
\text { oral } \\
\text { glucose } \\
\text { tolerance } \\
\text { test }\end{array}$} & \multirow[b]{2}{*}{$\begin{array}{c}\text { Low } \\
\text { lipo- } \\
\text { protein } \\
\text { lipase } \\
\text { activity }\end{array}$} \\
\hline $\begin{array}{c}\text { Ad lib- } \\
\text { itum } \\
\text { diet }\end{array}$ & $\begin{array}{c}\text { High- } \\
\text { carbo- } \\
\text { hydrate } \\
\text { Diet At }\end{array}$ & $\begin{array}{c}\text { Normal-fat } \\
\text { Diet B }\end{array}$ & $\begin{array}{l}\text { High-fat } \\
\text { Diet C } \$\end{array}$ & & & \\
\hline$m g / 100 \mathrm{ml}$ & $m g / 100 m l$ & $m g / 100 m l$ & $m g / 100 m l$ & & & \\
\hline$-\mathbb{T}$ & 273 & 241 & 235 & 0 & 0 & 0 \\
\hline $\begin{array}{l}200 \\
308 \\
200 \\
150 \\
202 \\
275\end{array}$ & $\begin{array}{l}\bar{z} \\
\overline{250} \\
\overline{275}\end{array}$ & $\begin{array}{l}250 \\
244 \\
- \\
- \\
280\end{array}$ & $\begin{array}{l}E \\
E \\
-\end{array}$ & $\begin{array}{l}0 \\
- \\
-\end{array}$ & $\begin{array}{l}0 \\
0 \\
0 \\
- \\
0\end{array}$ & $\begin{array}{l}\frac{0}{0} \\
- \\
-\end{array}$ \\
\hline $\begin{array}{r}273 \\
2,200 \\
4,613\end{array}$ & $\begin{array}{r}454 \\
600 \\
3,200\end{array}$ & $\begin{array}{r}- \\
250 \\
2,812\end{array}$ & $\frac{212}{2,200}$ & - & $\begin{array}{l}\mathbf{X} \\
\mathbf{X} \\
\mathbf{X}\end{array}$ & $\begin{array}{l}0 \\
0 \\
0\end{array}$ \\
\hline $\begin{array}{l}5,835 \\
4,747 \\
3,995\end{array}$ & $\begin{array}{l}748 \\
776 \\
500\end{array}$ & $\begin{array}{r}16,000 \\
3,142 \\
5,500\end{array}$ & E & $\underline{-}$ & $\begin{array}{l}\mathbf{0} \\
\mathbf{0} \\
\mathbf{0}\end{array}$ & $\begin{array}{l}\mathrm{X} \\
\mathrm{X} \\
\mathrm{X}\end{array}$ \\
\hline $\begin{array}{r}4,182 \\
1,241 \\
3,170 \\
1,551 \\
-256 \\
810\end{array}$ & $\begin{array}{r}4,500 \\
2,396 \\
1,892 \\
1,463 \\
800 \\
478 \\
577\end{array}$ & $\begin{array}{r}550 \\
1,432 \\
1,340 \\
524 \\
512 \\
285 \\
486\end{array}$ & $\begin{array}{l}528 \\
492 \\
401 \\
228 \\
132 \\
379\end{array}$ & $\begin{array}{l}0 \\
0 \\
0 \\
0 \\
0 \\
-\end{array}$ & $\begin{array}{l}0 \\
0 \\
0 \\
0 \\
0 \\
0\end{array}$ & $\begin{array}{l}0 \\
0 \\
0 \\
0 \\
0 \\
0 \\
0\end{array}$ \\
\hline 800 & 644 & 450 & - & - & 0 & 0 \\
\hline $\begin{array}{l}148 \\
800\end{array}$ & $\begin{array}{l}410 \\
750\end{array}$ & $\begin{array}{l}137 \\
250\end{array}$ & 107 & - & $\begin{array}{l}\mathbf{0} \\
\mathbf{0}\end{array}$ & $\begin{array}{l}\mathbf{0} \\
\mathbf{0}\end{array}$ \\
\hline
\end{tabular}

$\prod_{* *} \bar{T}=$ test not carried out.

$* * \mathrm{~T}=$ tendon.

t† $\mathrm{X}=$ present.

$¥$ Not hospitalized.

$\S \S \mathrm{S}=$ skin.

hyperlipemia, and another (H.G.) had a three-year-old sibling with decreased lipoprotein lipase activity but no evidence of lipemia.

Three additional patients, referred for study of hyperlipemia, were found to have maturity-onset diabetes. None had a family history of diabetes. Two were asymptomatic but had abnormal oral glucose tolerance tests. The third (H.K.) had a history of acidosis, increased concentrations of blood sugar when fasting, an abnormal oral glucose tolerance test, and attacks of acute abdominal crises. Her glycosuria was significantly reduced with oral tolbutamide. All three had coronary insufficiency or claudication.

Seven subjects are called "normal controls" for the purposes of this study, because their serum triglyceride levels and responsiveness to tolbutamide were within normal limits. However, they were not all free of disease. One had coronary insufficiency, and another had peripheral vascular disease, but none of the 7 showed clinical or laboratory evidence of hyperlipemia, diabetes, skin xanthomatosis, or abdominal symptoms. One had a family history of diabetes. Two had hypercholesteremia without hyperglyceridemia. Three of these $7 \mathrm{pa}-$ tients were fed high- and low-carbohydrate diets on the metabolic ward and failed to show significant changes in serum triglyceride levels in studies lasting several months.

The diets of the patients and controls, as well as relevant clinical data, are summarized in Table I. In addition to ad libitum diet periods, various controlled feeding 
regimens were utilized. At those times, feedings were composed solely of orally administered liquid formulas supplemented with minerals and vitamins (16). Protein, fat, and carbohydrate intakes $(\mathrm{P}: \mathrm{F}: \mathrm{C})$ were varied as follows: Diet $A, P: F: C=15: 0: 85$; Diet $B$, $P: F: C=15: 40: 45$; Biet $C, P: F: C=15: 70: 15$, all as percentages of total calories. Carbohydrate intakes exceeded $200 \mathrm{~g}$ per day on Diets $\mathrm{A}$ and $\mathrm{B}$ and during ad libitum feedings. Note that on all formula regimens the dietary carbohydrate consisted solely of glucose. Various dietary fats (corn oil, lard, and three triglycerides synthesized from linoleic acid, palmitic and oleic acids, and octanoic and decanoic acids) were utilized, with effects on serum triglyceride concentrations that have been described elsewhere $(1,2,16)$. Substitution of one fat for another had no apparent effect on the indexes of carbohydrate metabolism currently under study. All patients were ambulatory and were maintained at constant weights by appropriate adjustment of caloric intake. Tolbutamide studies were carried out only after serum triglyceride levels had stabilized on a given dietary regimen.

Laboratory procedure. Serum lipid concentrations were determined as previously described (16), and lipoprotein lipase activity was assayed. ${ }^{2}$

Blood glucose levels were determined by the glucostat enzymatic method, using glucose oxidase. ${ }^{3}$ Oral glucose tolerance tests were performed with a 100-g loading dose ; venous bleedings were carried out periodically for 3 to 5 hours. Tolerance tests were considered normal when fasting levels were lower than 100, 1-hour levels lower than 160 , and 2-hour levels lower than $110 \mathrm{mg}$ per 100 $\mathrm{ml}$ whole blood. After glucagon stimulation $(2 \mathrm{mg}$ intravenously) blood glucose levels were followed at 10-minute intervals for 60 minutes. Results were compared to those of Kirtley, Waife, Helmer, and Peck (17).

Responses to tolbutamide 4 ( $1 \mathrm{~g}$ in $20 \mathrm{ml}$ distilled water administered intravenously over a 2 -minute period to adults, $25 \mathrm{mg}$ per $\mathrm{kg}$ of body weight to children) were assayed in terms of changes in blood sugar concentration as described by Unger and Madison (18), and in insulin-like activity (ILA) by a modification of the rat epididymal fat pad assay (19). Blood samples were drawn at 20,30,60, and 90 minutes. The samples for sugar determinations were collected in tubes containing heparin and fluoride. Sera were frozen until assayed for ILA.

Assays of ILA were carried out after adjusting serum glucose contents to $250 \mathrm{mg}$ per $100 \mathrm{ml}$. Insulin standards ${ }^{5}$ were run with each analysis at levels of 476 and $38 \mu \mathrm{U}$ per ml medium. The conversion of glucose-

2 By Drs. Fredrickson and Ono (3) at the National Heart Institute, Bethesda, Md.

${ }^{3}$ Worthington Biochemical Corp., Freehold, N. J.

4 Intravenous tolbutamide kindly supplied by Dr. Thomas J. Vecchio, Upjohn Company, Kalamazoo, Mich.

${ }^{5}$ Crystalline insulin kindly supplied by Dr. W. R. Kirtley, Lilly Research Laboratories, Indianapolis, Ind.
6-C $\mathrm{C}^{14}$ to labeled triglyceride by rat epididymal fat pad tissue was taken as a function of ILA. (In the presence of insulin more than $80 \%$ of the radioactivity incorporated into triglyceride was found in the fatty acid moiety.) After the fat pad segments were washed three times in water to remove adhering labeled glucose, extractions were made in Dole's solvent system (20) (isopropyl alcohol : $\mathrm{n}$-heptane: $\mathrm{N}_{2} \mathrm{SO}_{4}, 40: 10: 1$ ). This was converted to two phases by addition of 8 parts of water and 12 of n-heptane. Fractions of upper phases containing all the triglyceride were taken to dryness in weighed scintillation-counting vials, so as to determine the weight of adipose tissue lipid in each assay. Phosphor solution (Liquifluor, ${ }^{6} 100 \mathrm{~g}$ 2,5-diphenyloxazole and $1.2 \mathrm{~g}$ 1,4-bis-2-(5-phenyloxazolyl)benzene per $\mathrm{L}$ of toluene) was added to each vial for liquid scintillation counting. Counts in test vials were normalized to a standard weight of adipose fat and calculated in terms of microunits of insulin per milliliter of serum by comparison with a logarithmic plot of the reference standards. Quadruplicate assays of serum ILA on any one day checked within $10 \%$. Analyses of sera assayed on separate days checked within $12 \%$.

\section{Results}

Table I summarizes the clinical data relevant in differentiating the two forms of hyperglyceridemia. By definition, the patients with fat-induced

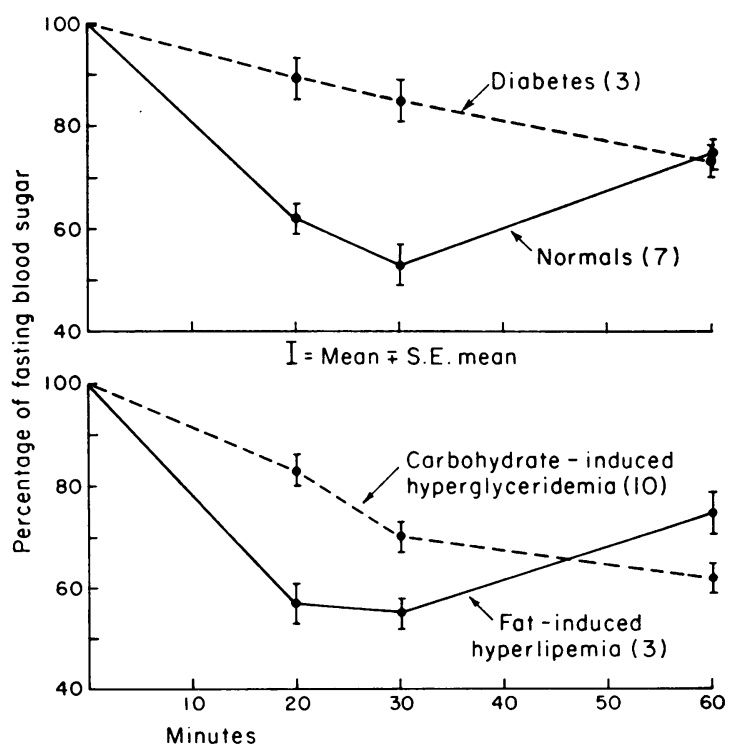

Fig. 1. Percentage of Changes in Blood Sugar LEVELS AFTER IV ADMINISTRATION OF TOLBUTAMIDE. Means of all tests (regardless of diet) are plotted in 4 groups of patients. Minutes $=$ minutes after tolbutamide administration.

6 Pilot Chemicals, Watertown, Mass. 
TABLE II

Changes in blood sugar levels after iv tolbutamide injection

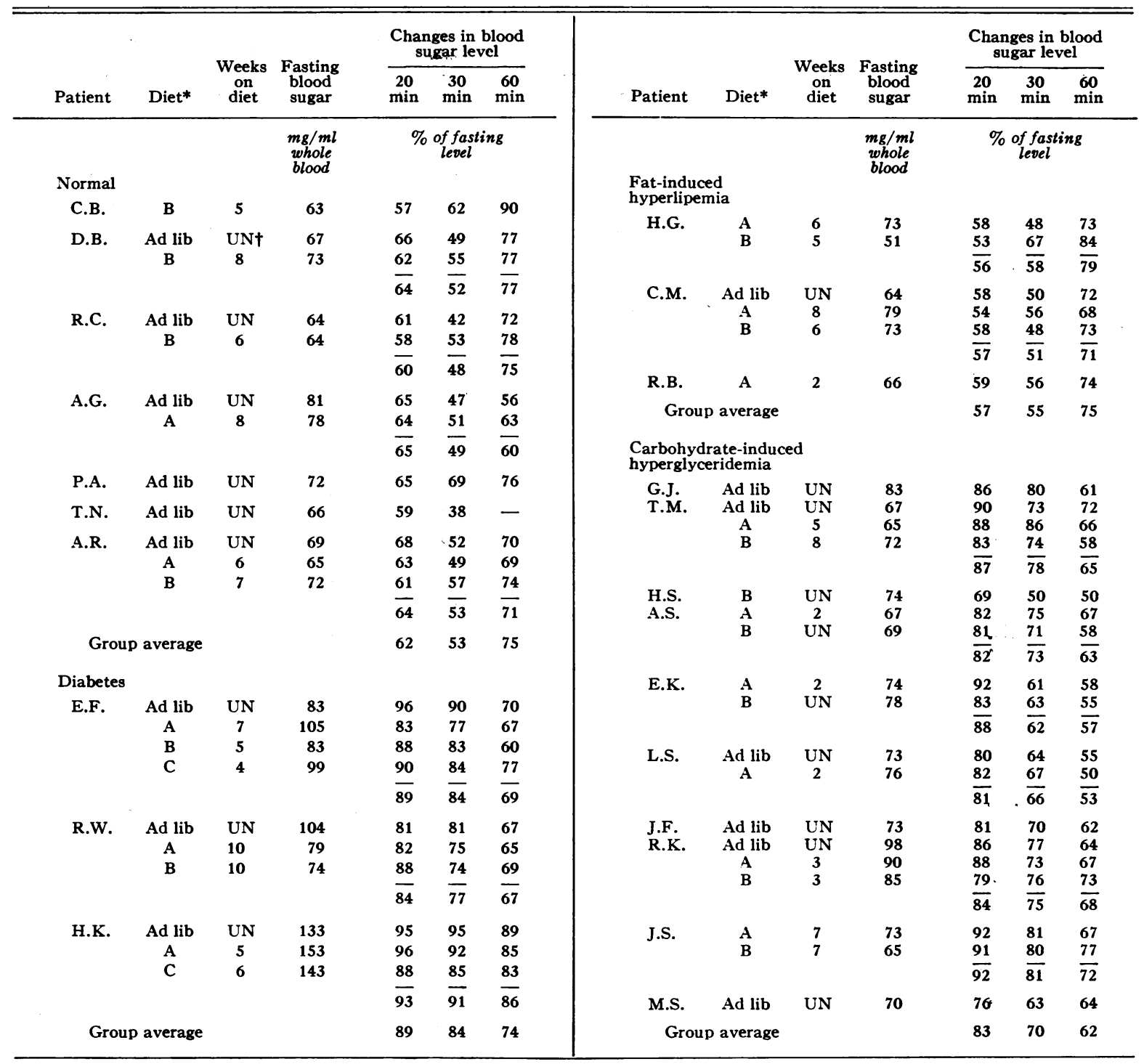

* See footnotes, Table I.

† UN $=$ undefined period, but greater than 3 weeks in all cases.

hyperlipemia had high levels of serum triglycerides on fat-containing diets and considerably lower concentrations on fat-free diets. Conversely, patients with carbohydrate-induced hyperglyceridemia had highest triglyceride levels on low-fat, high-carbohydrate diets. Lipoprotein lipase assays were normal in the carbohydrate-induced type, in normal subjects, and in diabetics; they were strikingly low in fat-induced hyperlipemia. By definition, oral glucose tolerance tests were not abnormal in any of 12 patients' with fat- or carbohydrate-induced hyperglyceridemia so tested; in 6 the hyperglycemic response to glucagon was normal, as judged by the criteria of Kirtley and colleagues (17).

Blood sugar responses to tolbutamide. Fortysix tests were carried out in 23 patients ( 7 normal, 3 diabetes, 3 fat-induced and 10 carbohydrateinduced hyperglyceridemia) on four diets. Changes in blood sugar levels induced by iv in- 
JEROME L. KNITTLE AND E. H. AHRENS, JR.

TABLE III

Changes in insulin-like activity (ILA) after iv tolbutamide injection

\begin{tabular}{|c|c|c|c|c|c|c|c|}
\hline \multirow[b]{2}{*}{ Patient } & \multirow[b]{2}{*}{ Diet* } & \multirow{2}{*}{$\begin{array}{l}\text { Weeks } \\
\text { on diet }\end{array}$} & \multirow{2}{*}{$\begin{array}{c}\text { Fasting } \\
\text { level }\end{array}$} & \multicolumn{4}{|c|}{ Changes in ILA at: } \\
\hline & & & & $20 \min$ & $30 \mathrm{~min}$ & $60 \min$ & $90 \mathrm{~min}$ \\
\hline & & & $\underset{\text { serum }}{\mu U / m l}$ & \multicolumn{4}{|c|}{ absolute increase in $\mu U / m l$ serum } \\
\hline D.B. & $\underset{B}{\text { Ad lib }}$ & $\mathrm{UN}^{*}$ & $\begin{array}{l}25 \\
40\end{array}$ & $\begin{array}{l}122 \\
\frac{160}{141}\end{array}$ & $\begin{array}{l}122 \\
\frac{140}{131}\end{array}$ & $\begin{array}{r}0 \\
-8 \\
-4\end{array}$ & $\begin{array}{l}-5 \\
-4 \\
-5\end{array}$ \\
\hline P.A. & Ad lib & UN & 105 & 79 & 49 & 7 & 4 \\
\hline T.N. & Ad lib & UN & 50 & 100 & 130 & - & - \\
\hline A.R. & $\begin{array}{c}\text { Ad lib } \\
\text { A } \\
\text { B }\end{array}$ & $\begin{array}{c}\text { UN } \\
6 \\
7\end{array}$ & $\begin{array}{l}38 \\
60 \\
30\end{array}$ & $\begin{array}{l}122 \\
130 \\
150 \\
134\end{array}$ & $\begin{array}{r}39 \\
80 \\
105 \\
75\end{array}$ & $\begin{array}{r}-2 \\
-12 \\
-4 \\
-6\end{array}$ & $\begin{array}{l}-9 \\
-9 \\
-1 \\
-5\end{array}$ \\
\hline \multicolumn{2}{|c|}{ Group average } & & & 114 & 96 & -1 & -2 \\
\hline \multicolumn{8}{|l|}{ Diabetes } \\
\hline E.F. & $\stackrel{\mathrm{A}}{\mathrm{C}}$ & $\begin{array}{l}7 \\
4\end{array}$ & $\begin{array}{l}85 \\
64\end{array}$ & $\frac{62}{62}$ & $\begin{array}{l}62 \\
97 \\
80\end{array}$ & $\begin{array}{l}51 \\
87 \\
69\end{array}$ & $\begin{array}{r}-21 \\
7 \\
-7\end{array}$ \\
\hline R.W. & $\begin{array}{c}\text { Ad lib } \\
\text { A } \\
\text { B }\end{array}$ & $\begin{array}{l}\text { UN } \\
10 \\
10\end{array}$ & $\begin{array}{r}74 \\
84 \\
130\end{array}$ & $\begin{array}{l}98 \\
91 \\
80 \\
90\end{array}$ & $\begin{array}{r}105 \\
96 \\
85 \\
95\end{array}$ & $\begin{array}{r}58 \\
81 \\
140 \\
93\end{array}$ & $\begin{array}{r}-5 \\
-10 \\
3\end{array}$ \\
\hline H.K. & $\stackrel{\mathrm{A}}{\mathrm{C}}$ & $\begin{array}{l}5 \\
6\end{array}$ & $\begin{array}{l}231 \\
180\end{array}$ & $\begin{array}{r}-1 \\
9 \\
4\end{array}$ & $\begin{array}{r}3 \\
40 \\
22\end{array}$ & $\begin{array}{l}55 \\
45 \\
50\end{array}$ & $\begin{array}{l}55 \\
54 \\
55\end{array}$ \\
\hline \multicolumn{2}{|c|}{ Group average } & & & 52 & 66 & 71 & 17 \\
\hline \multicolumn{8}{|c|}{$\begin{array}{l}\text { Fat-induced } \\
\text { hyperlipemia }\end{array}$} \\
\hline C.M. & $\underset{A}{\text { Ad lib }}$ & $\begin{array}{c}\text { UN } \\
8\end{array}$ & $\begin{array}{l}53 \\
37\end{array}$ & $\begin{array}{r}80 \\
162 \\
121\end{array}$ & $\begin{array}{r}87 \\
133 \\
110\end{array}$ & $\begin{array}{l}-14 \\
-2 \\
-8\end{array}$ & $\begin{array}{r}0 \\
-7 \\
-3\end{array}$ \\
\hline R.B. & A & 2 & 20 & 23 & 80 & 0 & - \\
\hline \multicolumn{2}{|c|}{ Group average } & & & 72 & 95 & -4 & -3 \\
\hline \multicolumn{8}{|c|}{$\begin{array}{l}\text { Carbohydrate-induced } \\
\text { hyperglyceridemia }\end{array}$} \\
\hline T.M. & $\underset{A}{\text { Ad lib }}$ & $\begin{array}{c}\mathrm{UN} \\
5\end{array}$ & $\begin{array}{l}83 \\
49\end{array}$ & $\begin{array}{l}26 \\
40 \\
33\end{array}$ & $\begin{array}{l}92 \\
84 \\
88\end{array}$ & $\begin{array}{r}111 \\
95 \\
103\end{array}$ & $\begin{array}{r}-8 \\
0 \\
-4\end{array}$ \\
\hline A.S. & $\begin{array}{l}\mathrm{A} \\
\mathrm{B}\end{array}$ & $\stackrel{2}{\mathrm{UN}}$ & $\begin{array}{l}55 \\
43\end{array}$ & $\begin{array}{l}45 \\
19 \\
32\end{array}$ & $\begin{array}{l}175 \\
209 \\
192\end{array}$ & $\begin{array}{l}227 \\
169 \\
198\end{array}$ & $\begin{array}{l}-1 \\
-8 \\
-5\end{array}$ \\
\hline E.K. & $\begin{array}{l}\mathrm{A} \\
\mathrm{B}\end{array}$ & $\stackrel{2}{\mathrm{UN}}$ & $\begin{array}{l}49 \\
32\end{array}$ & $\begin{array}{r}-9 \\
25 \\
8\end{array}$ & $\begin{array}{l}50 \\
73 \\
62\end{array}$ & $\begin{array}{l}251 \\
198 \\
225\end{array}$ & $\begin{array}{r}7 \\
16 \\
12\end{array}$ \\
\hline L.S. & $\underset{A}{\text { Ad lib }}$ & $\underset{2}{\mathrm{UN}}$ & $\begin{array}{l}67 \\
46\end{array}$ & $\begin{array}{l}51 \\
48 \\
50\end{array}$ & $\begin{array}{l}96 \\
63 \\
80\end{array}$ & $\begin{array}{r}148 \\
83 \\
116\end{array}$ & $\begin{array}{l}-8 \\
-1 \\
-5\end{array}$ \\
\hline J.S. & $\begin{array}{l}\mathrm{A} \\
\mathrm{B}\end{array}$ & $\begin{array}{l}7 \\
7\end{array}$ & $\begin{array}{r}107 \\
59\end{array}$ & $\begin{array}{l}250 \\
\frac{133}{192}\end{array}$ & $\begin{array}{l}237 \\
121 \\
179\end{array}$ & $\begin{array}{l}238 \\
106 \\
172\end{array}$ & $\frac{\overline{4}}{4}$ \\
\hline M.S. & Ad lib & UN & 105 & 57 & - & 0 & 一 \\
\hline \multicolumn{2}{|c|}{ Group average } & & & 62 & 121 & 136 & 0 \\
\hline
\end{tabular}

* See footnotes to previous tables. 
jection of tolbutamide in relation to the various diets are shown in Table II. No consistent effects of diet could be detected when interdietary comparisons were made in individual patients or in disease groups, although responses were tested during the feeding of two or more diets in 15 patients. As a general rule increased carbohydrate intakes did not improve the responsiveness to tolbutamide in any of the four patient groups. In fact, in 3 patients with carbohydrate-induced hyperglyceridemia (T.M., E.K., and R.K.) a somewhat greater decrease was seen at 20 minutes on Diet B than on ad libitum or Diet A. Nevertheless, their responses on Diet B were still smaller in degree than those of all normal subjects on any diet.

For graphic presentation in Figure 1, the raw data were normalized by relating them to fasting blood sugar concentrations at $100 \%$. Percentage decreases were plotted as group averages of the averaged individual responses on all diets. Figure 1 (upper) presents the responses in 7 normal and 3 diabetic patients. The findings are in accord with the much larger series of data presented by Unger and Madison (18). Each normal subject showed a prompt decrease below $68 \%$ at 20 minutes and a secondary rise at 60 minutes. In the diabetics, however, the response was distinctly different: levels were greater than $80 \%$ at 20 minutes, and at 60 minutes the curve was still downward.

Figure 1 (lower) presents the results in carbohydrate- and fat-induced hyperglyceridemia. In all of the latter group a prompt decrease in blood sugar occurred, reaching a minimum at 20 to 30 minutes, and the normal secondary rise at 60 minutes was seen in each case. By contrast, in 9 of 10 cases of carbohydrate-induced hyper-

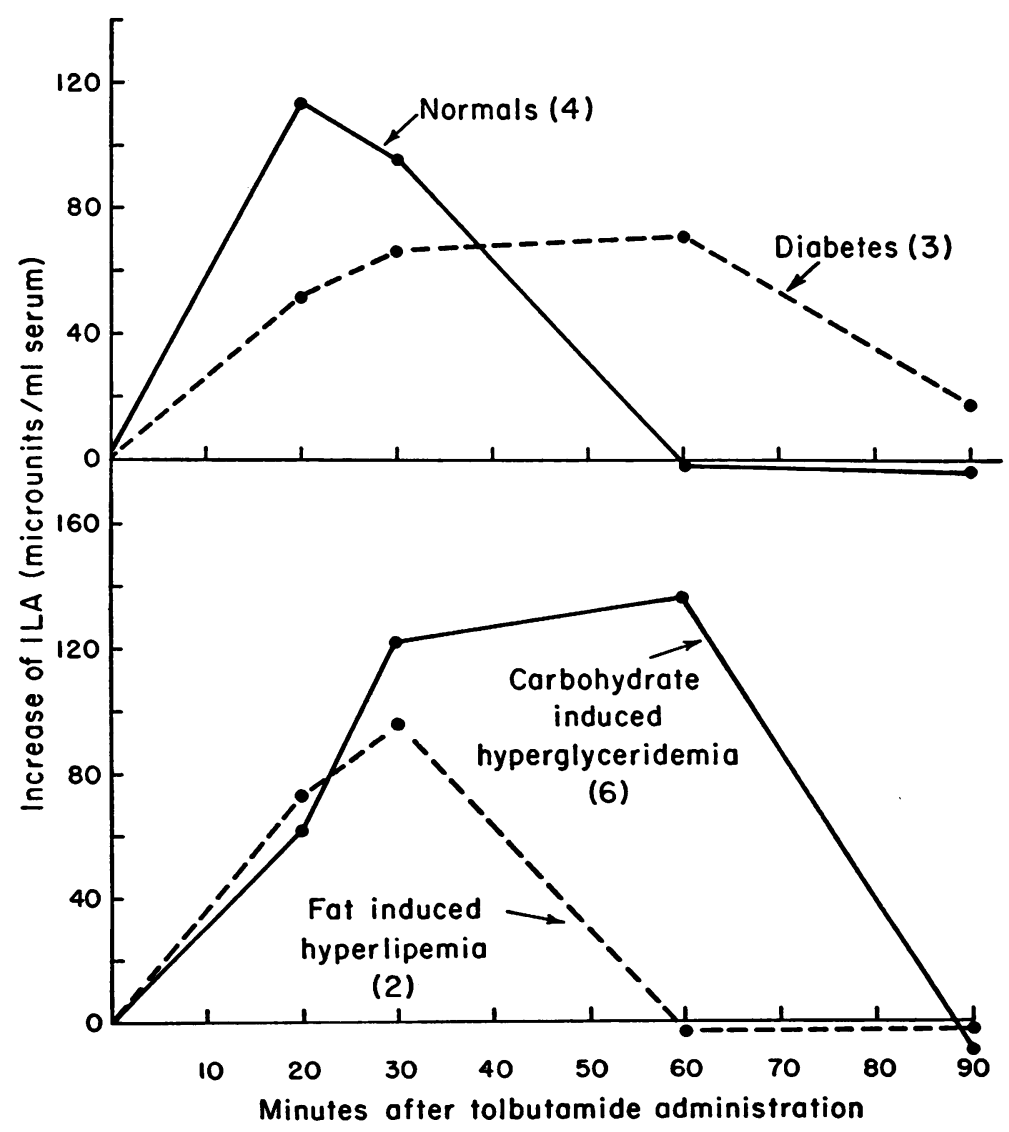

Fig. 2. Absolute increases in SERUM ILA ABOVe fasting levels After iv ADMinistration of tolbutamide. Means of all tests (regardless of diet) are plotted in $\mathbf{4}$ groups of patients. 
glyceridemia the response at 20 minutes was $76 \%$ of the fasting level or higher, and in all $10 \mathrm{sub}$ jects the blood sugar curve failed to rise at 60 minutes.

Responses to tolbutamide at 20 and 30 minutes were significantly different in the normal and carbohydrate-induced groups ( $\mathrm{p}<0.01$ by the $t$ test on percentage differences from fasting levels).

Fasting blood sugar levels (Table II) were not significantly different in the two forms of hyperglyceridemia and in the normal group but were slightly elevated in the 3 diabetics.

Responses of serum ILA to tolbutamide (Table III). Twenty-eight ILA tests were carried out in 15 subjects ( 4 normal, 3 diabetes, 2 fat-induced and 6 carbohydrate-induced hyperglyceridemia) on four diets. No systematic effect of diet could be detected when interdietary comparisons were made in individual patients or in disease groups. Variations in ILA levels beyond those ascribable to methodologic error were noted in 3 of 11 patients tested at different times on various diets (J.S., C.M., and R.W.) ; these were variations in degree but not in pattern of response. Since these differences were not consistently related to amounts of carbohydrate and fat in the diet, multiple tests in individual patients on various diets were averaged, and the averages in each group were averaged for comparison in Figure 2. Values are expressed as microunits of ILA per $\mathrm{ml}$ of serum above fasting levels.

Figure 2 (upper) shows the mean increase in ILA provoked by iv infusion of tolbutamide in 4 normal and 3 diabetic subjects. The normal group displayed a more rapid response with peak values at 20 or 30 minutes and a rapid decrease to fasting levels at 60 minutes. Diabetic subjects showed elevated values at 60 minutes, which did not return toward fasting levels until 90 minutes.

Figure 2 (lower) presents the results in the two forms of hyperglyceridemia. The two fatinduced hyperlipemic patients showed peak values at 20 or 30 minutes and a return to fasting levels at 60 minutes, as in the normal controls. However, the mean curve in carbohydrate-induced hyperglyceridemia was characterized by an elevated ILA at 60 minutes and return to fasting levels at 90 minutes, as in the diabetics.

Differences in ILA at 60 minutes in 4 normal versus 6 carbohydrate-induced hyperglyceridemia patients were significant at a level of $\mathrm{p}<0.05(t$ test on absolute increase in ILA from fasting levels) but at 20 minutes only at a level of $\mathrm{p}<0.1$. These statistical analyses include the data obtained in 1 of the 6 patients (M.S.) with carbohydrate-induced hyperglyceridemia who had a normal ILA response to tolbutamide. Her blood sugar response (Table II) was abnormal at 60 minutes and resembled those of the 9 other patients with this form of hyperglyceridemia.

In general, then, ILA and blood sugar responses to tolbutamide were inversely related. Patients with decreased tolbutamide responsiveness as measured by sluggish decreases in blood sugar concentration had prolonged increases in ILA (diabetics and carbohydrate-induced hyperglyceridemia), whereas those who had a prompt decrease in blood sugar after tolbutamide also had prompt increases and decreases in ILA (normal subjects and fat-induced lipemia).

\section{Discussion}

The data presented indicate that patients with carbohydrate-induced hyperglyceridemia have abnormal responses to tolbutamide resembling those seen in diabetes suspects and in mild diabetes. Unger and Madison (18) report a delayed and prolonged fall in blood sugar after tolbutamide administration in maturity-onset diabetics and in mild diabetics with normal blood sugar concentrations when fasting. Abnormal responses were found also in diabetes suspects (children of two diabetic parents and mothers of large stillborn babies) by Jackson and Keller (21). Yalow, Black, Villazon, and Berson (11) described a prolonged slow rise in serum insulin levels in maturity-onset diabetics after acute tolbutamide stimulation or glucose ingestion. Finally, Beigelman and Tranquada (22) found higher levels of fasting ILA in the blood of diabetes suspects than in normals. In the present study we have found abnormal responses in 9 of 10 patients with carbohydrate-induced hyperglyceridemia but in none of three patients with fat-induced hyperlipemia. Apparently carbohydrate-induced hyperglyceridemia may represent an abnormal pancreatic response to tolbutamide stimulation or inefficient peripheral utilization of the insulin released or release of an inactive or bound form of insulin 
-alternatives currently debated in the pathogenesis of diabetes $(11,23)$.

A relationship between diabetes and hyperlipemia has been noted repeatedly in the last five decades. Indeed, Bradley, Eccles, and Freelender (14) noted that hyperlipemia may be an early manifestation of diabetes mellitus. In 1955, Adlersberg and Wang (24) discussed 5 patients with idiopathic hyperlipemia, mild diabetes, and severe vascular disease, and Waddell, Geyer, Harley, and Stare (25) postulated a "pancreatic insufficiency state" in their hyperlipemic patients who displayed abnormal carbohydrate tolerance tests. In 1961, Bierman and Hamlin (26) described the phenomenon of carbohydrate-induced hyperglyceridemia in 5 patients with diabetes mellitus.

It has not been determined whether the hyperglyceridemia induced by dietary carbohydrate represents increased synthesis, decreased utilization, "trapping" in the plasma, or a combination of these factors. To this end, Farquhar, Reaven, Gross, and Wagner (27) studied triglyceride kinetics in the $\mathrm{D}<1.006$ fraction of plasma in 2 patients with carbohydrate-induced hyperglyceridemia after their plasma glyceride concentrations had been stabilized at two levels by feeding highand low-carbohydrate diets, respectively. These investigators concluded that hepatic triglyceride synthesis is increased and that net removal of the particulate triglyceride is insufficient to prevent expansion of pool size.

The postulated imbalance between synthesis and utilization that accounts for the accumulation of triglycerides in the plasma presumably occurs during the transitional weeks immediately after the replacement of fat by carbohydrate calories. At this time the rate of production temporarily exceeds the rate of peripheral utilization. Soon, however, this imbalance is corrected, since eventually each patient's triglyceride concentration stabilizes at a new (but higher) level. During this new steady state, when on logical grounds the stimulus to lipogenesis would seem to be maximal, there must also be a greater net utilization (or clearance) of newly synthesized triglycerides. In normal subjects, reasoning from Antonis and Bersohn's results (9), clearance finally exceeds production, and serum triglyceride levels return to normal, for they found a rise, then a plateau, and finally a fall in serum triglyceride over a 4to 9-month period. We have noted the same sequence of events in several patients with the complete cycle lasting only 1 to 4 weeks. Why, then, do certain patients maintain increased concentrations of triglycerides in the plasma for many months, perhaps indefinitely?

The rise in plasma glycerides on high-carbohydrate diets may be caused by a partial defect in peripheral clearance of triglyceride-rich $\beta$-lipoprotein particles. Indeed, we (28) and Bierman (29) have shown that these particles are transported in the plasma as $\beta$-lipoproteins of density $<1.019$. What relationship, if any, is there between the metabolism of $\beta$-lipoprotein triglycerides and the abnormal response to tolbutamide described in the present study?

Insulin governs the rate of re-esterification of fatty acids with glycerophosphate (30), as well as the rate of entry of glucose into muscle and adipose tissue cells. Thus, a defect in insulin action in the periphery might result in a decreased rate of formation of intracellular glyceride. An impairment in glycerol esterification in the adipose cell may lead to a slower than optimal transfer into the cell of the glycerides synthesized in the liver and transported to the periphery in the form of triglyceride-rich $\beta$-lipoprotein fat particles. The evidence thus far available is consistent with the proposal that a block in peripheral utilization of triglycerides, which may be caused by an abnormality in insulin metabolism, leads to a damming back of triglyceride-rich $\beta$-lipoproteins originating in the liver. To test this premise it will be necessary to measure the rate at which these triglycerides can be taken up in peripheral tissues, and to compare the height of the threshold for clearance of $\beta$-particles in normal subjects and in patients with hyperglyceridemia. Although Bierman and Hamlin's finding of normal chylomicron clearance in diabetes (31) is of considerable interest, it does not bear directly upon the question at hand-that of $\beta$-particle clearance.

The role of the liver in the development of carbohydrate-induced hyperglyceridemia also remains to be clarified, as well as the effect of insulin on the production of triglycerides by the liver. In one of our patients (T.M.) with carbohydrateinduced hyperglyceridemia, who was each day for 2 weeks given sufficient insulin by injection to 
produce symptoms of hypoglycemia, there was no effect on serum triglyceride concentrations. After oral tolbutamide administration, however, a marked decrease in serum triglycerides was noted. As these preliminary results are extended, comparing the effects of endogenously secreted insulin (stimulated by tolbutamide) with exogenous insulin will be especially significant, since in the former case the liver is exposed first to the outpouring of insulin from the pancreas, whereas injected insulin may have its primary effect peripherally. Shipp and Munroe (32) noted an interesting fall in triglyceride levels in patients with mild diabetes treated with oral sulfonylurea.

\section{Summary}

1. In ten patients with carbohydrate-induced hyperglyceridemia the response to a single intravenous dose of tolbutamide was measured by following changes in the concentration of blood sugar and serum insulin-like activity. The decrease in blood sugar was smaller in degree and the rebound was delayed, when compared to controls and three patients with fat-induced hyperlipemia. Levels of insulin-like activity rose more slowly than normally, a response previously noted in maturity-onset diabetes.

2. This evidence suggests that carbohydrateinduced hyperglyceridemia is in some manner allied to the prediabetic state in maturity-onset diabetes. We propose that the normal rate of clearance of plasma triglycerides may be determined in part by the action of insulin on peripheral tissues.

\section{References}

1. Ahrens, E. H., Jr., J. Hirsch, K. Oette, J. W. Farquhar, and Y. Stein. Carbohydrate-induced and fat-induced lipemia. Trans. Ass. Amer. Phycns 1961, 74, 134.

2. Ahrens, E. H., Jr., and N. Spritz. Further studies on fat- and carbohydrate-induced lipemia in man: reduction of lipemia by feeding fat in Biochemical Problems of Lipids, A. C. Frazer, Ed. Amsterdam, Elsevier, 1963, vol. 1, p. 304.

3. Fredrickson, D. S., K. Ono, and L. L. Davis. Lipolytic activity of post-heparin plasma in hyperglyceridemia. J. Lipid Res. 1963, 4, 24.

4. Farquhar, J. W. Personal communication.

5. Bierman, E. L. Personal communication.

6. Furman, R. H. Personal communication.
7. Havel, R. J., and R. S. Gordon, Jr. Idiopathic hyperlipemia: metabolic studies in an affected family. J. clin. Invest. 1960, 39, 1777.

8. Robinson, C. W., and R. H. Furman. Lipoprotein lipase activity (free fatty acid release) induced by in vitro sonic oscillation of serum from heparinresistant hyperlipemic subjects. Clin. Res. 1961, 9, 145.

9. Antonis, A., and I. Bersohn. Serum-triglyceride levels in South African Europeans and Bantu and in ischaemic heart-disease. Lancet 1960, 1, 998.

10. Seltzer, H. S. Quantitative effects of glucose, sulfonylureas, salicylate, and indole-3-acetic acid on the secretion of insulin activity into pancreatic venous blood. J. clin. Invest. 1962, 41, 289.

11. Yalow, R. S., H. Black, M. Villazon, and S. A. Berson. Comparison of plasma insulin levels following administration of tolbutamide and glucose. Diabetes 1960, 9, 356.

12. Salt, H. B., O. H. Wolff, A. Nestadt, and J. K. Lloyd. Control of lipaemia in children with diabetes mellitus. The role of insulin and the effects of a diet rich in unsaturated fatty acids. Lancet 1960, 1, 71 .

13. Hirsh, E. F., B. P. Phibbs, and L. Carbonaro. Parallel relation of hyperglycemia and hyperlipemia (esterified fatty acids) in diabetes. Arch. intern. Med. 1953, 91, 106.

14. Bradley, R. F., R. Eccles, and A. E. Freelender. Hyperlipemia as an early manifestation of diabetes mellitus (abstract). Program for the 21st Annual Meeting of the American Diabetes Ass., June 25, 1961.

15. Holt, L. E., Jr., F. X. Aylward, and H. G. Timbres. Idiopathic familial lipemia. Bull. Johns Hopk. Hosp. 1939, 64, 279.

16. Ahrens, E. H., Jr., J. Hirsch, W. Insull, Jr., T. T. Tsaltas, R. Blomstrand, and M. L. Peterson. Influence of dietary fats on serum-lipid levels in man. Lancet 1957, 1, 943.

17. Kirtley, W. R., S. O. Waife, O. M. Helmer, and F. B. Peck. Effect of purified glucagon (hyperglycemic-glycogenolytic factor, HGF) on carbohydrate and corticoid metabolism in normal and diabetic subjects. Diabetes 1953, 2, 345.

18. Unger, R. H., and L. L. Madison. A new diagnostic procedure for mild diabetes mellitus. Diabetes 1958, 7, 455.

19. Renold, A. E., D. B. Martin, Y. M. Dagenais, J. Steinke, R. J. Nickerson, and M. C. Sheps. Measurement of small quantities of insulin-like activity using rat adipose tissue. I. A proposed procedure. J. clin. Invest. 1960, 39, 1487.

20. Dole, V. P. A relation between non-esterified fatty acids in plasma and the metabolism of glucose. J. clin. Invest. 1956, 35, 150.

21. Jackson, W. P. U., and P. Keller. Intravenous tolbutamide and plasma insulin-like activity in probable "pre-diabetics." Diabetes (suppl.) 1962, 11, 138. 
22. Beigelman, P. M., and R. E. Tranquada. Serum insulin-like activity in untreated diabetics. Diabetes 1962, 11, 179.

23. Antoniades, H. N., H. M. Pyle, and J. A. Bougas. Tolbutamide and regulation of endogenous insulin. Diabetes (suppl.) 1962, 11, 34.

24. Adlersberg, D., and C. Wang. Syndrome of idiopathic hyperlipemia, mild diabetes mellitus, and severe vascular damage. Diabetes 1955, 4, 210.

25. Waddell, W. R., R. P. Geyer, N. Harley, and F. J. Stare. Abnormal carbohydrate metabolism in patients with hypercholesterolemia and hyperlipemia. Metabolism 1958, 7, 707.

26. Bierman, E. L., and J. T. Hamlin III. The hyperlipemic effect of a low-fat, high-carbohydrate diet in diabetic subjects. Diabetes 1961, 10, 432.

27. Farquhar, J. W., G. M. Reaven, R. Gross, and R. Wagner. Rate of plasma triglyceride synthesis in carbohydrate-induced lipemia. J. clin. Invest. (abstract) 1963, 42, 930.
28. Oette, K., S. Grundy, and E. H. Ahrens, Jr. Unpublished data.

29. Bierman, E. L. An unusual group of fat particles in plasma of hyperlipemic subjects maintained on high-carbohydrate, low-fat diets. J. clin. Invest. (abstract) 1963, 42, 917.

30. Bally, P. R., G. F. Cahill, Jr., B. Leboeuf, and A. E. Renold. Studies on rat adipose tissue in vitro. $\mathrm{V}$. Effects of glucose and insulin on the metabolism of palmitate-1-C ${ }^{14}$. J. biol. Chem. 1960, 235, 333.

31. Bierman, E. L., and J. T. Hamlin III. The effect of insulin and glucagon on the removal of $\mathrm{C}^{14}$-labeled particulate triglyceride from plasma in man. $\mathrm{Me}$ tabolism 1963, 12, 666.

32. Shipp, J. C., and J. F. Munroe. Effects of sulfonylureas compounds on hyperlipemia and hypercholesteremia in patients with minimal impairment of glucose tolerance. Diabetes (suppl.) 1962, 11, 69. 